\title{
IL-20: biological functions and clinical implications
}

\author{
Chi-Chen Wei ${ }^{1,2,6}$, Yu-Hsiang Hsu ${ }^{3}$, Hsing-Hui Li ${ }^{1}$, Yo-Ching Wang ${ }^{3}$, Mei-Yi Hsieh ${ }^{3,6}$, \\ Wei-Yu Chen ${ }^{1}$, Chung-Hsi Hsing ${ }^{4,5}$ \& Ming-Shi Chang ${ }^{3,4,6, *}$ \\ ${ }^{1}$ Institute of Basic Medical Sciences, Medical College, National Cheng Kung University, Tainan, Taiwan; \\ ${ }^{2}$ Department of Medical Technology, Chung Hwa College of Medical Technology, Tainan, Taiwan; ${ }^{3}$ Grad- \\ uate Institute of Biochemistry and Molecular Biology, Medical College, National Cheng Kung University, \\ Tainan, Taiwan; ${ }^{4}$ Institute of Biopharmaceutical Sciences, Medical College, National Cheng Kung University, \\ Tainan, Taiwan; ${ }^{5}$ Department of Anesthesiology, Chi-Mei Medical Center, Tainan, Taiwan; ${ }^{6}$ Department of \\ Medical Research, Chi-Mei Medical Center, Tainan, Taiwan
}

Received 4 January 2006; accepted 7 April 2006

(C) 2006 National Science Council, Taipei

Key words: angiogenesis, atherosclerosis, IL-20, inflammation, psoriasis, rheumatoid arthritis

\begin{abstract}
Summary
IL-20 belongs to the IL-10 family and plays a role in skin inflammation and the development of hematopoietic cells. Little is known about its other biological functions and clinical implications, however. Updated information about IL-20, such as its identification, expression, receptors, signaling, biological activities, and potential clinical implications, is illustrated in this review based on our research and on data available in the literature. Our studies of IL-20 show that it is a pleiotropic cytokine with potent inflammatory, angiogenic, and chemoattractive characteristics. Inflammation and angiogenesis are essential for the pathogenesis of rheumatoid arthritis and atherosclerosis. Based on in vitro data and clinical samples, we demonstrated that IL-20 is involved in the diseases of rheumatoid arthritis and atherosclerosis. In addition, we found in our studies that IL-20 signaled through different molecules in several cells. The present review presents the clinical implications of IL-20 in rheumatoid arthritis and atherosclerosis. It may provide new therapeutic options in the future.
\end{abstract}

Abbreviations: Akt kinase - a serine/threonine kinase; ApoE - apolipoprotein E; bFGF - basic fibroblast growth factor; CIA - collagen-induced arthritis; COX - cyclooxygenase; ERK - extracellular signalregulated protein kinase; EST - expressed sequence tag; IFN - interferon; Jak - Janus kinase; LDL - lowdensity lipoprotein; MCP - monocyte chemoattractant protein; MIP - macrophage inflammatory protein; MMP - matrix metalloproteinase; Ox-LDL - oxidized low-density lipoprotein; PMA - phorbol myristate acetate; RA - rheumatoid arthritis; RANTES - regulated upon activation, normal T-cell expressed and secreted; RASFs - rheumatoid arthritis synovial fibroblasts; RT-PCR - reverse transcriptase polymerase chain reaction; STAT - signal transducers and activators of transcription; TNF- $\alpha$ - tumor necrosis factoralpha; VEGF - vascular endothelial cell growth factor

\section{Introduction}

*To whom correspondence should be addressed. phone +886 6-2353535 ext. 5677, Fax +886-6-2741694, E-mail: mschang@ mail.ncku.edu.tw

This work was supported by a grant from Chi-Mei Medical Center, Tainan, Taiwan.
IL-10 is a pleiotropic cytokine that acts on many different cell types [1]. It was originally identified as an immunosuppressive cytokine [2], but it also plays an immunostimulatory role [3-5]. The IL-10 
family was determined recently after the discovery of several IL-10-related cytokines, including IL-19 [6], IL-20 [7], IL-22 [8], IL-24 [9], and IL-26 [10]. Despite a partial homology in their amino acid sequences, they are dissimilar in their biological functions. IL-19, first discovered in LPS-treated monocytes [6], induces monocytes to produce IL-6 and TNF- $\alpha$ [11], and CD4-positive $\mathrm{T}$ cells to produce Th2 cytokines; it is also associated with asthma [12]. Stimulating HepG2 human hepatoma cells with IL-22 upregulates the production of acute phase reactants such as serum amyloid A, $\alpha 1$-antichymotrypsin, and haptoglobin [13]. IL-22 protects hepatocytes by activating STAT3 and the increased expression of anti-apoptotics and betadefensins 2 and $3[14,15]$. IL-24 expression was upregulated in wound healing and during the in vitro differentiation of a melanoma cell line [9]. IL-26 was induced by the transformation of T lymphocytes with Herpesvirus saimiri [10], and targeted epithelial cells through IL-20R1 and IL10R2 [16, 17]. The overexpression of IL-20 in transgenic mice caused neonatal death as well as skin abnormalities, including aberrant epidermal differentiation [7]. IL-20 selectively enhanced multipotential hematopoietic progenitors in vitro and in vivo [18]. Other biological functions and clinical implications of IL-20 are unknown. Updated information about IL-20 - its identification, receptors, signaling, biological activities, and potential clinical implications - is illustrated in this review based on the data in the literature as well as on our own recent experiments.

\section{IL-20}

IL-20 was initially identified from the EST databases using an algorithm designed to identify translated sequences containing both a signal sequence and one or more amphipathic helices commonly found in helical cytokines [7]. The discovery of this full-length protein sequence was based on a structure prediction technique through a signal sequence and four amphipathic helix profiles. The amino acid sequences of IL-20 and IL-10 are $28 \%$ identical and IL-20 was consequently classified as a member of the IL-10 family. Both human and mouse IL-20 contain 176 amino acids and share $76 \%$ amino acid sequence identity. Protein crystallographic analysis of IL-10 indicates that it forms an intercalating dimer [19]; nevertheless, the recombinant human IL-20 protein produced in BHK and in baculovirus cells seems to form a monomer instead of an intercalating dimer [7].

Using PCR analysis, we also isolated an alternatively spliced transcript variant of IL-20 from human cDNA libraries. Exon 4 was deleted in the human short-variant of IL-20 (GenBank accession number AY876922). In addition, a mouse short-form of IL-20 was also identified (unpublished data). Tissue distribution analysis demonstrated that both human and mouse shortforms are tissue-specific. The short-form variant of human IL-20 was found in lung tissue [20], while the short-form variant of mouse IL-20 was expressed in brain tissue only.

Homology screening of the National Center for Biotechnology Information in the rat highthroughput genome-database was conducted using human IL-20 cDNA sequences as a query. We identified the rat IL-20 genomic clone and the fulllength cDNA of rat IL-20 (accession number DQ229286). Full-length cDNA of rat IL-20 was then amplified from testis tissue using RT-PCR with gene-specific primers and further verified using DNA sequencing. The alignment of human, mouse, and rat IL-20 is shown in Figure 1A.

The human IL-20 gene was mapped to a $195-\mathrm{kb}$ region on chromosome 1q32, which also includes IL-10, IL-19, and IL-24 [7]. The other two IL-10related cytokines, AK155 (IL-26) and IL-22, are on chromosome 12q15 [21]. Clustering of family members may be the result of gene duplication with subsequent divergence of function and regulation. The murine IL-20 gene is in the syntenic region on mouse chromosome 1 .

\section{Receptors and signaling}

The receptor complex for IL-20 has been identified as one pairwise combination of receptor subunits, IL-20R1 and IL-20R2 [7]. These two proteins comprise a heterodimeric IL-20 receptor, structurally similar to the IL-10 receptor. Within the IL-10 family, IL-19, IL-20, and IL-24 exhibit substantial sharing of receptor complexes. IL-19 and IL-24 also signal through the IL-20R1/IL-20R2 heterodimer [21]. In addition, IL-20 and IL-24, but not IL-19, bind to another receptor complex, composed of IL-22R1 and IL-20R2 [21, 22]. 
(A)

Human. IL-20

Mouse. IL-20

Rat . IL-20

Human . IL-20

Mouse. IL-20

Rat . IL-20

Human. IL-20

Mouse. IL-20

Rat . IL-20

(B)

Human. IL-20RI

Mouse. IL-20RI

Rat. IL-20R1

Human. IL-20R

Mouse. IL-20RI

Rat. IL-20R1

Human. IL-20RI

Mouse. IL-20RI

Rat . IL-20R1

Human. IL-20R1

Mouse. IL-20RI

Rat . IL-20RI

Human. IL-20RI

Mouse. IL-20RI

Rat. IL-20RI

Human. IL-20RI

Mouse. IL-20R

Rat . IL-20R1

Human. IL-20R

Mouse. IL-20R1

Rat. IL-20R1

Human. IL-20R

Mouse. IL-20RI

Rat . IL-20RI

Human. IL-20RI

Mouse. IL-20RI

Rat . IL-20RI

Human. IL-20RI

Mouse. IL-20R

Rat . IL-20RI
MKASSLAFSLLSAAFYLLWTPSTGLKTLNLGSCVIATNLOEIRNGFSDIRGSVQAKDGNI MKGFGLAFGLFSAVGFLLWTPLTGLKTLHLGSCVITANLQAIQKEFSEIRDSVQAEDTNI MRGFRLAFGLFSVWGFLWTPLTGLKTLHLGSCVITANLQAIQKEFSEIRHSVQAEDENI

$* . \quad * * * * * \ldots . * * * * * * * * * * * * * * * * . * * * * * .: * * * * * * * * * * * *$

DIRILRRTESLQDTKPANRCCLLRHLLRLYLDRVFKNYQTPDHYTLRKISSLANSFLTIK DIRILRTTESLKDIKSLDRCCFLRHLVRFYLDRVFKVYQTPDHHTLRKISSLANSFLI IK DVRILRTTESLKDTKLSDRCCFLRHLVRFYLDRVFKVYQTPDHHTLRK ISSLANSFLI IK $*: * * * * * * * *: * * \quad: * * * * * * * *: *: * * * * * * * * * * * * *: * * * * * * * * * * * * * * *$

KDLRLCHAHMTCHCGEEAMKKYSQILSHFEKLEPQAAVVKALCELDILLQWMEETE KDLSVCHSHMACHCGEEAMEKYNQILSHFIELELQAAVVKALGELGILLRWMEEML KDLSVCHSHMACHCGEEAMEKYNQILSHFTELELOAAVVKALGELGILLRWMKOML $* * *: * *: * *: * * * * * * * * * * * * * * * * *$ : $: * * * * * * * * * * * * * . * * * * * *::$

MR - . - - APGRPALRPLPLPPLLLLLLAAPWGRAVPCVSGGLPKPANITFLSINMKNVLO MHTPGTPAPGHPDPPPLLLLTLLLLLAAS- -GRAVPCVFCGLPKPTNITFLSINMKNVLH MHTPETPAPGRLAPRPPLLPTLLLLLAAS- -GRAVPYAFCGLPKPTNITFLSINMKNVLH $*: \quad * * *: \quad * \quad * \quad * * * * *: * * * * *, * * * * * * * * * * * * * * * * *$

WTPPEGLOGVKVTYTVOYFIYGOKKWLNKSECRNINRTYCDLSAETSDYEHOYYAKVKAI WNPPESLHGVEVTYTVQYFIYGQKKWLNASKCGSINRTYCDLSVETSDYEHQFYAKVKAI WSRPEGLHGVEVTYTVOYFIYGORKWLSASKCTSISRTYCDLSVETSDYEROFYAKVKAI $* . * *, * * *: * * * * * * * * * * * * * * *, *:^{*}, * * * * * * * *, * * * * * * * * * * * * * * *$

WGTKCSKWAESGRFYPFLETOIGPPEVALTTDEKSISVVLTAPEKWKRNPEDLPVSMOOI WEARCSEWAETERFYPFLETQVSPPEVALTTGEKSISIALTAPEKWKRNPQDHTVSMQQI WETRCSEWAETERFYPFLETOVSPPEVALTTGEKSISIALTAPEKWKRNPODSPVSMOOV $*:: * *: * * *: * * * * * * * *: . * * * * * * *, * * * * *: . * * * * * * * * * * * * *, . * * * *:$

YSNLKYNVSVLNTKSNRTWSOCVTNHTLVLTWLEPNTLYCVHVESFVPGPPRRAOPSEKO YPNLKYNVSVYNTKSRRTWSQCVTNSTLVLSWLEPNTLYCVHVESLVPGPPRLPMPSQKQ YPNLKYNVSVYDTKSGRTWSQCITNSTLVLSWLEPSTLYCVRVESLVPGPTRLPLP-WKQ $* . * * * * * * *: * * * * * * * * *: * * * * * *: * * * *, * * * * *: * * *: * * * *, *, * * *$

CARTLKDQSSEFKAKI IFWYVLPVSITVFLFSVMGYSIYRYIHVGKEKHPANLILIYGNE CISTLEVOTSAWKAKVIFWYVFLTSVIVFLFSAIGYLVYRYIHVGKEKHPANLVLIYRNE CISTLEVQTSTWKVKVIFWYILPTSVIVFLFSA IGYSAYRYIQVGKEKHPANLVLIYRNE $* * * * * * * * * * * * * * ;: * * * * * * *, * * * * * * * * * * * * * * * * * * * * * * *$

FDKRFFVPAEKIVINFITLNI SDDSKISHODMSLLGKSSDVSSLNDPOPSGNLRPPOEEE IGTRVFEPTETITLNFITFSMLDDTKISPKDMNLLDKSSDDISVNDPEHNEAWEPHWEEV IGKRVFNPTE- -TLHSITLSTLDDSKISQTDMNLLDRSSDEVSVNNPEFSGSWEPNWEDA

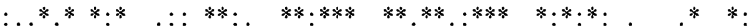

EVKHLGYASHLMEIFCDSEENTEGTSLTOOESLSRTIPPDKTVIEYEYDVRTTDICAGPE EGQHLGCSSHLMDAVCGAEQRDGDTSLTQHGWLNSTIPTGETDTEPQYKV-LSDFYGEGE EGOHLGYSSHLVDIVCGVEOSDRDTSLTOHAWFNSPMPTGEADFEPOYKV-LADFYKEGR

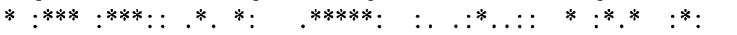

EQELSLQEEVSTQGTLLESQAALAVLCPOTLOYSYTPQLQDLDPLAQEHTDSEEGPEEEP IQLSCEPEEAARTE - . . . . . . - - KISEPLVTSANLDPQLEDLHHLCQEHTVSEDGPEEET DOQFCGSEEAARTE -.........-KLAEPOATLANLDPOLEDLOHLGOEHPGSEARPEEEA

$*$. **.: $\quad: * * . . * * * * * . * *^{* *}, * * * * * *$

STTLVDWDPOTGRLCIPSLSSFDQDSEGCEPSEGDGLGEEGLLSRLYEEPAPDRPPGENE SITVVDWDPQTGRLCIPSLPIFGRDPENYGHYERDQLLEGGLLSRLYENQAPDKPEKENE STTLVDWDPRTGRLCIPSLPIFGHDLENYGCYERDHLSEDGLLSRLYENQAPDKSEEENE $* *: * * * * *: * * * * * * * * . * .: * * . \quad * * * * * * * * * * * *: * * *: . * * *$

TYLMQFMEEWGLYVQMEN

NCLTRFMEEWGLHVQMES

NYLIQFMEEWGLHVOMES

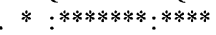


(C)

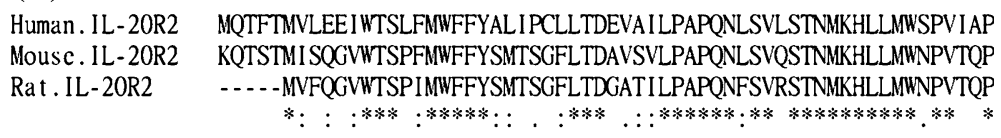

Human. IL-20R2

Mouse. IL-20R2

Rat . IL-20R2

Human. IL-20R2

Mouse. IL-20R2

Rat . IL-20R2

Human. IL-20R2

Mouse. IL-20R2

Rat . IL-20R2

Human. IL-20R2

Mouse. IL-20R2

Rat . IL-20R2

Human. IL-20R2

Mouse. IL-20R2

Rat . IL-20R2
GETVYYSVEYQGEYESLYTSHIWIPSSWCSLTEGPECDVTDDITATVPYNLRVRATLGSQ GETVLYCVEYOCEYESLYMSHIWIPSSOCSPTKSLECDVTDDITATVPYNFRVKAMLGSQ GETVFYFVQYQGEYESLYMSHIWIPSSQCSPTKGLECDVTDDVTATVPYNFRVMAMLGSQ $* * * * * * * * * * * * * * * * * * * * * * * * * *, \quad * * * * * * * * * * * * * * * * * * * * * *$

TSAWSILKHPFNRNSTILTRPGMEITKDGFHLVIELEDLGPQFEFLVAYWRREPGAEEHV TSAWSNLEHPFNRNATVLTPPRMEVTEHGLHLVIELEDLGPQFEFLVYYRREPGAAEHV SSAWSNLEHPFNRNATVLTPPRMEVTEHGLHLVVELEDLGPQFEFLVVYWRMEPGAVERV

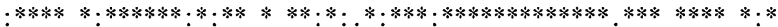

KMVRSGGIPVHLETMEPGAAYCVKAOTFVVAIGRYSAFSOTECVEVOGEAIPLVLALFAF KMVRSGDIPVHLETMEPGAMYCVKAQALVKAIGRHSAFSQPTCVEMQGESLPLALALFAF KVVRSGDIPVHLETMDPGVMYCVKAQALVKTIGRHSAFSQPTCVEMQGESLPLALALFAF $* * * * * * * * * * * * * * * * * * * * * * ; * * * * * * * * * *, * * * * * * * ; * * * * * * *$

VGFMLILVVVLFVWKMGRLLQYSCCPVVVLPTLKITNSPQKLISCRREEVDACATAVM VGFML ILVVVLLSWKMGQLLRYSCCPAVLPDTLKITSSSQKLISCRKEEVDACAVAVL VGFVLILVVALLSWWKMGQLLRYSCCPAVLPDTLKVTSSSQKLIRCRKEEVDACAVTVL $* * *: * * * * . * * * * * *: * * * * * * *, * * * * * * * * * * * * * * * * *: * * * * * * * .:_{*}^{*}:$

SPEELLRAWIS - -

SSEHLFGVWISOT

SSEHLFGVWISQT

****.***

Figure 1. Comparison of human, mouse, and rat IL-20 and their receptors. Full-length coding protein for human, mouse, and rat (A) IL-20, (B) IL-20 R1, and (C) IL-20R2 were aligned. “*” = identical amino acid sequences; ":" = similar amino acid sequences; "." = fewer amino acid similarities than sequence alignments with ":".

Homology screening of the National Center for Biotechnology Information rat high-throughput genome-database was conducted using human IL20R1 and IL-20R2 cDNA sequences as a query. We identified the full-length cDNA of rat IL-20 R1 and IL-20R2 (accession numbers XM218776 and DQ222846, respectively). Full-length cDNA of rat IL-20R1 and IL-20R2 was then amplified from testis tissue using RT-PCR with gene-specific primers and further verified using DNA sequencing. Alignment of human, mouse, and rat IL-20 R1 and IL-20 R2 is shown in Figure 1B and C.

Recombinant IL-20 protein stimulates the common Jak-STAT signal transduction pathway through STAT3 in HaCaT and BHK cells transfected with two IL-20 receptor subunits, IL-20R1 and IL-20R2. In unstimulated $\mathrm{HaCaT}$ cells, STAT3 staining was predominantly in the cytosol. IL-20 stimulation of $\mathrm{HaCaT}$ cells resulted in a distinct nuclear translocation of STAT3, but not of STAT1 [7].

Little is known about signal transduction mechanisms coupled to the IL-20 receptor complexes, IL-20R1/IL-20R2 and IL-22R1/IL-20R2, except that they all function partly through JAK-STAT pathways. Several observations showed that IL-20 signaled through different pathways in different cell types: STAT3 in keratinocyte cell lines $(\mathrm{HaCaT})$ [7]; ERK1/2 in RA synovial fibroblasts [23]; p38 kinase, JNK, and ERK1/2 in endothelial cells (HUVECs) [20]. All three subunits of IL-20 receptors are co-expressed in these cells, but they transmit different signals to IL-20. Additional studies will be required to determine the key molecules in the signaling transduction pathways that induce the various biological effects of IL-20.

\section{Expression profiles of IL-20 and its receptors}

The expression pattern of IL-20 in a variety of human tissue types was determined using traditional RT-PCR, real-time RT-PCR, and in situ hybridization. IL-20 was mainly expressed in LPStreated monocytes, and in skin, kidney, lung, and placenta tissue. Several cell lines derived from prostate, pancreas, skin, lung, colon, and breast tissue also expressed IL-20 at different level [24]. 


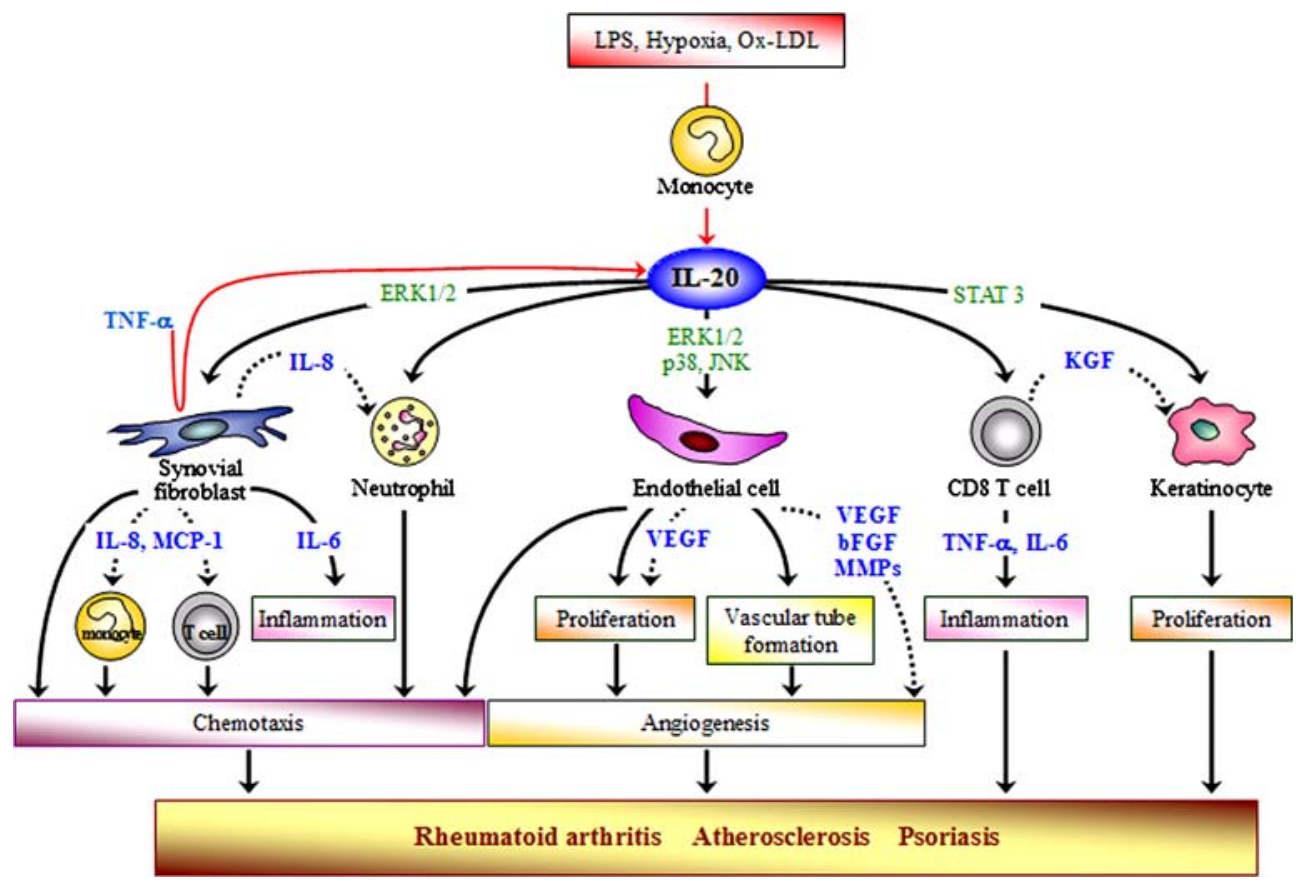

Figure 2. IL-20 is associated with psoriasis, rheumatoid arthritis (RA), and atherosclerosis. IL-20 can be induced by LPS, hypoxia or oxidized LDL (Ox-LDL) in monocytes and TNF- $\alpha$-stimulated RA synovial fibroblasts. Synovial fibroblasts, neutrophils, endothelial cells, CD8-positive T cells and keratinocytes are target cells for IL-20. IL-20 acts as a chemoattractant and an angiogenesis factor by itself and also an inducer for other chemokines and angiogenesis factors. In rheumatoid arthritis, IL-20 acts on fibroblasts using an autocrine pathway, and induces the secretion of MCP-1, IL-6, and IL-8. Directly (solid line) or indirectly (dotted line) recruited neutrophils, monocytes and $\mathrm{T}$ cells in the joints cause more severe inflammation and result in joint swelling and bone destruction. The induced IL-20 in monocytes by the stimuli of LPS, oxidized LDL or hypoxia condition in combination with upregulated IL-20 receptors on endothelial cells promote migration, proliferation and vascular tube formation of endothelial cells. The angiogenic effects of IL-20 on endothelial cells include both direct activity of IL-20 by itself (solid line) and indirect activity (dotted line) mediated by the induced VEGF, IL-8, bFGF, and MMPs. IL-20 may trigger CD8-positive T cells infiltrated in lesional psoriatic skin and mediate proliferative reactions to sustain the hyperproliferation of the keratinocytes in psoriasis by producing KGF. It may also activate CD8-positive T cells to produce TNF- $\alpha$ and IL-6 and initiate a cascade of inflammation. Chemotaxis, angiogenesis and inflammation are the hallmarks for rheumatoid arthritis, atherosclerosis and psoriasis.

Because no comprehensive analysis of IL-20 protein expression in the tissues had been previously performed, we conducted an analysis of its expression profile on a tissue microarray containing 37 different healthy essential tissues using immunohistochemistry staining with mouse monoclonal anti-hIL-20 antibody. Table 1 provides a summary of the previous data compared with our new data about the expression pattern of IL-20 using immunohistochemical (IHC) staining on tissue microarray. IL-20 protein was expressed in several healthy tissue types (Table 1). IL-20 was expressed in several specific cell-types among these tissues, namely squamous epithelial cells, endothelial cells, macrophages, and lymphocytes. IHC staining with cell-specific markers in these tissues was needed to further confirm this result. These data will provide valuable references for further investigation of the biological functions and clinical implications of IL-20 in humans.

The expression pattern of IL-20 receptor, IL20R1, IL-20R2, and IL-22R1 in a variety of human tissue types is summarized in Table 2. Of these tissue types, skin and lung demonstrated abundant expression of all three receptors. Similarly, only transcripts of IL-20 receptor subunits have been determined so far. The protein levels of IL-20R1 and IL-20R2 need to be confirmed using immunohistochemical staining with specific antibodies.

\section{Clinical implications of IL-20}

Based on the expression profiles of IL-20 and its receptors, an increasing number of the characteristics of the biological activities of IL-20 have been 
Table 1. Expression of IL-20 in normal tissues.

\begin{tabular}{|c|c|c|}
\hline & IL-20 $\operatorname{protein}^{\mathrm{a}}$ & IL-20 transcript \\
\hline Skin & + & $+{ }^{b}$ \\
\hline Buccal mucosa & + & ND \\
\hline Tongue & + & ND \\
\hline Esophagus & + & ND \\
\hline Stomach & + & ND \\
\hline Small intestine & + & $--^{\mathrm{b}}$ \\
\hline Colon & + & ND \\
\hline Appendix & + & ND \\
\hline Liver & + & $-{ }^{\mathrm{b}}$ \\
\hline Gall bladder & - & ND \\
\hline Pancreas & + & ND \\
\hline Nasal mucosa & + & ND \\
\hline Lung & + & $+{ }^{\mathrm{b}}$ \\
\hline Submandibular gland & + & ND \\
\hline Tonsil & + & ND \\
\hline Thymus & + & ND \\
\hline Spleen & + & $-{ }^{\mathrm{b}}$ \\
\hline Lymph node & + & ND \\
\hline Kidney & + & $+{ }^{\mathrm{b}}$ \\
\hline Ureter & + & ND \\
\hline Prostate & + & ND \\
\hline Breast & + & ND \\
\hline Uterine cervix & + & ND \\
\hline Uterus & - & ND \\
\hline Endometrium & + & ND \\
\hline Fallopian tube & + & ND \\
\hline Ampulla of Vater & + & ND \\
\hline Ovary & + & ND \\
\hline Placenta & - & $+^{\mathrm{b}}$ \\
\hline Testis & - & ND \\
\hline Seminal vesicle & + & ND \\
\hline Parathyroid & - & ND \\
\hline Thyroid gland & - & ND \\
\hline Adrenal gland & - & ND \\
\hline Eye-retina & - & ND \\
\hline Skeletal muscle & - & ND \\
\hline Brain & + & $-{ }^{\mathrm{b}}$ \\
\hline Heart & ND & $-^{\mathrm{b}}$ \\
\hline Bone marrow & ND & $-{ }^{\mathrm{b}}$ \\
\hline Fetal liver & ND & $-{ }^{\mathrm{b}}$ \\
\hline monocytes & ND & $+^{\mathrm{c}}$ \\
\hline LPS-treated monocytes & ND & $+^{\mathrm{c}}$ \\
\hline NK cells & ND & $-^{\mathrm{c}}$ \\
\hline $\mathrm{B}$ cells & ND & $-^{\mathrm{c}}$ \\
\hline $\mathrm{T}$ cells & ND & $-^{\mathrm{c}}$ \\
\hline
\end{tabular}

Different assays used to determine the expression of IL-20 in normal tissues are indicated.

atissue microarray analysis.

${ }^{\mathrm{b}} \mathrm{RT}$-PCR [7, 20, 25].

creal-time RT-PCR [24, 26]

ND: not determined.
Table 2 Expression of IL-20 receptor subunits in normal tissues

\begin{tabular}{|c|c|c|c|}
\hline & IL-20R1 & IL-20R2 & IL-22R1 \\
\hline Brain & $++^{a}$ & $-{ }^{\mathrm{a}}$ & $-{ }^{\mathrm{a}}$ \\
\hline Heart & $++^{a}$ & $+{ }^{a}$ & $-^{\mathrm{a}}$ \\
\hline Kidney & $+^{\mathrm{a}}$ & $-{ }^{\mathrm{a}}$ & $+{ }^{\mathrm{a}, \mathrm{e}, \mathrm{f}}$ \\
\hline Spleen & $-^{\mathrm{a}}$ & $-{ }^{\mathrm{a}}$ & $-{ }^{\mathrm{a}}$ \\
\hline Liver & $++^{\mathrm{a}, \mathrm{b}}$ & $-{ }^{\mathrm{a}} ;+^{\mathrm{b}}$ & $+^{\mathrm{a}, \mathrm{b}, \mathrm{e}, \mathrm{f}}$ \\
\hline Colon & $++^{a}$ & $-{ }^{\mathrm{a}}$ & $+{ }^{\mathrm{a}, \mathrm{f}}$ \\
\hline Lung & $+{ }^{\mathrm{a}, \mathrm{c}}$ & $++^{\mathrm{a}, \mathrm{c}}$ & $+{ }^{\mathrm{a}, \mathrm{c}}$ \\
\hline Small intestine & $++^{\mathrm{a}}$ & $+{ }^{\mathrm{a}}$ & $+{ }^{\mathrm{a}, \mathrm{e}, \mathrm{f}}$ \\
\hline Muscle & $+^{\mathrm{a}}$ & $+{ }^{\mathrm{a}}$ & $-{ }^{\mathrm{a}}$ \\
\hline Stomach & $++^{a}$ & $-{ }^{\mathrm{a}}$ & $--^{\mathrm{a}, \mathrm{f}}$ \\
\hline Testis & $++^{\mathrm{a}}$ & $+{ }^{a}$ & $-{ }^{\mathrm{a}}$ \\
\hline Placenta & $+{ }^{\mathrm{a}}$ & $+{ }^{\mathrm{a}}$ & $-{ }^{\mathrm{a}}$ \\
\hline Salivary gland & $+{ }^{\mathrm{a}}$ & $+{ }^{\mathrm{a}}$ & $-{ }^{\mathrm{a}}$ \\
\hline Thyroid gland & $++^{\mathrm{a}}$ & $-{ }^{\mathrm{a}}$ & $+{ }^{\mathrm{a}}$ \\
\hline Adrenal gland & $++^{\mathrm{a}}$ & $+{ }^{a}$ & $+{ }^{\mathrm{a}}$ \\
\hline Pancreas & $+{ }^{\mathrm{a}, \mathrm{b}}$ & $-{ }^{\mathrm{a}} ;+/-^{\mathrm{b}}$ & $+{ }^{a, b}, e, f$ \\
\hline Ovary & $+{ }^{\mathrm{a}}$ & $+{ }^{\mathrm{a}}$ & $-^{\mathrm{a}}$ \\
\hline Uterus & $+^{\mathrm{a}}$ & $-{ }^{\mathrm{a}}$ & $-{ }^{\mathrm{a}}$ \\
\hline Prostate & $++^{\mathrm{a}}$ & $-{ }^{\mathrm{a}}$ & $-{ }^{\mathrm{a}}$ \\
\hline Skin & $+{ }^{a, b}, c, d$ & $+{ }^{a}, b, c, d$ & $+\mathrm{a}, \mathrm{b}, \mathrm{c}, \mathrm{f}$ \\
\hline Pheripheral blood leukocytes - & $-{ }^{\mathrm{a}} ;+^{\mathrm{b}}$ & $+{ }^{\mathrm{a}}$ & $-{ }^{\mathrm{a}}$ \\
\hline Bone marrow & $-^{\mathrm{a}}$ & $-{ }^{\mathrm{a}} ;+{ }^{\mathrm{b}}$ & $-{ }^{\mathrm{a}}$ \\
\hline Fetal brain & $-^{\mathrm{a}}$ & $-{ }^{\mathrm{a}}$ & $-{ }^{\mathrm{a}}$ \\
\hline Fetal liver & $-{ }^{\mathrm{a}}$ & $-{ }^{\mathrm{a}}$ & $+{ }^{\mathrm{a}}$ \\
\hline monocytes & $-{ }^{b}$ & $+{ }^{b}$ & $-{ }^{\mathrm{b}}$ \\
\hline NK cells & $-{ }^{b}$ & $+{ }^{b}$ & $-{ }^{\mathrm{b}}$ \\
\hline B cells & $-{ }^{b}$ & $+{ }^{b}$ & $+{ }^{b}$ \\
\hline $\mathrm{T}$ cells & $-{ }^{b}$ & $+{ }^{b}$ & $-{ }^{\mathrm{b}}$ \\
\hline
\end{tabular}

Different assays used to determine the expression of IL-20R1, IL-20R2, and IL-22R1 in normal tissues are indicated.

${ }^{\mathrm{a}} \mathrm{RT}$-PCR [7, 20, 22, 25, 27].

${ }^{b}$ real-time RT-PCR $[24,26]$.

${ }^{\mathrm{c}}$ In situ hybridization [7, 22].

${ }^{\mathrm{d}}$ Immunohistochemical staining [25].

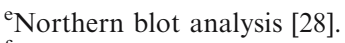

${ }^{\mathrm{f}}$ Micro-array analysis [29].

demonstrated. Although much remains to be explained about the physiological and pathogenic mechanisms of action of IL-20, current data support their association with several diseases and their therapeutic potential. An overview of the known or speculated functional properties of IL-20 and their association with diseases is illustrated in this section.

\section{IL-20 and psoriasis}

Psoriasis is an inflammatory dermatosis characterized by abnormal epidermal proliferation. Pre- 
vious studies indicate that $\mathrm{T}$ cells and cytokines are of major importance in the pathophysiology of this immune-mediated disorder [7, 22, 30, 31]. Several proinflammatory cytokines are cutaneously and systemically overexpressed in psoriasis, particularly type-1 cytokines (e.g., IL-2, -6, -8, and -12 ; IFN- $\gamma$; and TNF- $\alpha$ ), the overexpression of which is responsible for the initiation, maintenance, and recurrence of skin lesions [31].

There are several lines of evidence suggesting a role for IL-20 and its receptor in psoriasis. First, the overexpression of IL-20 in transgenic mice causes neonatal death and psoriasis-like skin abnormalities, including hyperkeratosis, thickened epidermis, and aberrant epidermal differentiation. Second, all three IL-20 receptor subunits are expressed in the skin [22] and are markedly upregulated in human psoriatic skin [7, 32]. In addition, IL-20 stimulates signal transduction through STAT3 in HaCaT cells [7], and STAT3 is activated in human psoriatic lesions [33]. Evidence from our recent study [29] further confirms that IL-20 and its receptors are involved in the pathogenesis of psoriasis. Immunohistochemical staining with specific antibodies and an RT-PCR assay detected overexpression of IL-20, IL-20R1, and IL-20R2 in the keratinocytes of lesional psoriatic skin [25, 33]. Increased expression of IL-20 and functional IL-20 receptor complex in lesional skin from psoriasis patients was believed to alter the interactions between endothelial cells, immune cells, and keratinocytes, which leads to dysregulation of keratinocyte proliferation and differentiation. Nevertheless, the expression levels of IL-20R1 and IL-20R2 in the uninvolved skin from psoriasis patients varied with different individuals [25], but they were higher than those in the lesional skin of most patients. These results are consistent with those from a recent study [34] proposing that an imbalance in the IL-20 receptor complexes might contribute to their suspected pathogenic effects. Other than keratinocytes, CD8-positive $\mathrm{T}$ cells might also serve as target cells for IL-20. Real-time RT-PCR demonstrated that IL-20 treatment upregulated the transcripts of keratinocyte growth factor (KGF) [25]. Recently, we further found that IL-20 induced the expression of TNF- $\alpha$ in CD8-positive T cells. Induction of $\mathrm{TNF}-\alpha$ protein was also detected in the conditioned medium of IL-20-stimulated CD8-positive $\mathrm{T}$ cells (unpublished data). CD8-positive $\mathrm{T}$ cells infiltrate lesional psoriatic skin and are considered important in the pathogenesis of psoriasis [30, 35]. Thus, IL-20 may trigger CD8-positive $\mathrm{T}$ cells locally and mediate proliferative reactions to sustain the hyperproliferative status of the keratinocytes in psoriasis by producing KGF. It may also activate CD8-positive $\mathrm{T}$ cells to produce $\mathrm{TNF}-\alpha$ and initiate a cascade of inflammation.

These observations suggest that inhibiting IL20 activity might therefore be considered for the therapy of psoriasis. This might be achieved, for instance, by using a neutralizing antibody to IL-20 [25] or an antagonistic soluble extracellular domain of the IL-20R1/IL-20R2 receptor complex [22].

\section{IL-20 and Rheumatoid arthritis}

Rheumatoid arthritis (RA) is an autoimmune disease characterized by acute and chronic inflammation of the synovial joints and causes them to loss function and ends in bone destruction. Although the etiology of RA is unclear, the molecules involved in the inflammatory process are becoming better understood. Cytokines, as essential signal molecules in inflammation, are known to be involved in the pathogenesis of RA. Vasculitis with recruitment and activation of cytokine-producing inflammatory cells, including monocytes and macrophages, T- and B-lymphocytes, and neutrophils, are characteristically found in affected tissue. Inflammatory cytokines such as IL- $1 \beta$, IL- 6 , IL- 8 , and TNF- $\alpha$ are overexpressed in the affected tissue, in the synovial fluid of affected joints, and in the circulation of RA patients. The effects of IL- $1 \beta$ and TNF- $\alpha$ on synovial cells, fibroblasts, bone cells (osteoblasts and osteoclasts), and chondrocytes are all compatible with the pathophysiology of RA. These inflammatory cytokines are produced through the continuous activation of $\mathrm{T}$ cells, which then interact with monocytes and macrophages in RA [36]. Growing evidence indicates that innate immune cells such as neutrophils and mast cells are responsible for a vast majority of acute and ongoing inflammation $[37,38]$.

IL-10 is crucial in the progression of RA. Endogenous IL-10 partly suppressed the production of TNF- $\alpha$, IL- $1 \beta$, and IL- 8 from synovial macrophages and synoviocytes. Furthermore, IL10 was confirmed to have beneficial effects in a 
collagen-induced arthritis (CIA) animal model because it reduced joint swelling and cytokine production, indicating that IL-10 in vivo may have a protective role [39-41].

That IL-20 may be involved in inflammatory joint diseases was reported in a recent study [42] that used immunohistochemistry combined with digital microscopic analysis to demonstrate the expression of IL-20 in the inflamed synovium of patients with rheumatoid arthritis. Immunohistochemical staining indicated that not only IL-20, but also all three of its receptors, were expressed in synovial membranes and synovial fibroblasts (RASFs) derived from the synovial tissue of RA patients and CIA rats, a model thought to mimic human RA [23]. This finding offers a possibility about the role of IL-20 involved in RA. We speculate that IL-20 may play a role in RA by via autocrine pathway.

Furthermore, we demonstrated that RA patients expressed significantly higher levels of IL-20 in synovial fluid than that in controls [23]. The recruitment of neutrophils, macrophages, and lymphocytes into joint tissue is a hallmark of RA in humans. Several chemokines, including IL-8, MCP-1, RANTES, and MIP-1, were expressed in tissue from the inflamed joints of patients with RA [43-49]. Our migration assay also confirmed that IL-20 induced neutrophil chemotaxis in vitro, and IL-20 upregulated the production of IL-6, IL-8, and MCP-1 by RASFs [23]. IL-8 recruits neutrophils and MCP-1 is a potent chemoattractant of monocytes and T cells. Therefore, IL-20 by itself is a chemoattractant and an inducer of other chemokines. The proinflammatory cytokines, $\mathrm{TNF}-\alpha$ and IL- $1 \beta$ were shown to induce IL-20 in RA fibroblast-like synoviocytes [42]. The clinical success of therapeutic strategies of neutralizing TNF- $\alpha(\mathrm{EN}-$ BREL) or IL-1 $\beta$ has highlighted their relevance to the pathogenesis of RA [50-52]. Overall, we propose that macrophages and TNF- $\alpha$-stimulated synovial fibroblasts to secrete IL-20, which acts on fibroblasts using an autocrine pathway, and induces the secretion of MCP-1 and IL-8. Directly and indirectly recruited neutrophils, monocytes, and $\mathrm{T}$ cells into joints causes more severe inflammation that increased joint swelling or bone destruction.

These data suggest that an IL-20 antagonist might be helpful for RA therapy. Soluble rat IL20R1 extracellular domain in expression vector was introduced into CIA rats using intramuscular electroporation five and ten days after inducing primary CIA. It significantly decreased the symptoms of arthritis and the progression of the disease in CIA rats [23].

\section{IL-20 and atherosclerosis}

Atherosclerosis is a chronic inflammatory disease of the arterial wall characterized by the progressive accumulation of lipids, extracellular matrix, and cells, including macrophages, $\mathrm{T}$ lymphocytes, and smooth muscle cells [53]. Inflammation plays a major role in atherosclerosis plaque disruption and thrombosis, and, therefore, greatly influences the occurrence of coronary syndromes and mortality [54-56]. IL-10, important in atherosclerosis lesion formation and stability, is a protective factor against the effect of environmental pathogens on atherosclerosis [57].

Angiogenesis plays a crucial role in the progression of atherosclerosis plaque. Studies that demonstrated a higher prevalence of neovascularization in lesions with plaque rupture, mural hemorrhage, or unstable angina showed the clinical importance of the neovascularization of plaque [58, 59].

Endothelial cells expressed IL-20R1 and IL20R2 [60] and might be target cells for IL-20. IL20 induced proliferation and migration on human umbilical vein endothelial cells (HUVECs) [20]. The formation of new microvessels in human atherosclerotic plaque is associated with high cellular proliferation in the plaque [61]. IL-20 also induced the expression of the angiogenesis factors bFGF and VEGF, and of matrix metalloproteinase-2 (MMP-2) in HUVECs [20]. VEGF plays a crucial role in the development of atherosclerosis and increases in hypercholesterolemia [62]. VEGF protein and mRNA increase in unstable plaques $[63,64]$. Thus, IL-20 may affect the progression of atherosclerosis through VEGF. MMP-9 and -2 have been implicated in the development of atherosclerosis and plaque rupture in acute coronary syndromes (ACS) [65]. Our data demonstrated that IL-20 induced MMP-2 transcript in HUVECs, indicating that IL-20 may play a crucial role in atherosclerotic plaque growth and stability, thus determining the disease outcome. All these biological activities of IL-20 were also observed in human microvessel endothelial cells (HMECs) 
[20]. IL-20 also induced vascular tube formation in vitro and in vivo [20]. Furthermore, IL-20 and its IL-20R1/IL-20R2 receptor complex were expressed in the atherosclerosis plaque of humans and ApoE-deficient (ApoE ${ }^{-/-}$) mice (unpublished data). IL-20 expression was detected in both the foam cells and the endothelial cells lining the microvessels of atherosclerotic lesions, and IL20R1/IL-20R2 expression was detected in microvascular endothelium. We postulate that increased expression of IL-20 by macrophages and endothelial cells may serve as paracrine or autocrine factors for endothelial cells. In addition, we found that oxidized LDL, an inflammatory stimulus in atherosclerosis plaque and hypoxia condition, dramatically increased IL-20 expression by monocytes and macrophages (unpublished data). The increased IL-20 secretion in combination with upregulated IL-20 receptors on endothelial cells would promote proliferation, migration and vascular tube differentiation of endothelial cells, thereby stimulating angiogenesis.

Heuze-Vourc'h et al. recently reported that IL20 was an anti-angiogenesis cytokine that downregulated COX-2 and $\mathrm{PGE}_{2}$ in human bronchial epithelial and endothelial cells [66]. IL-20dependent inhibition of COX-2 and $\mathrm{PGE}_{2}$ occurred through the IL-22R1/IL-20R2 dimers and inhibited experimental angiogenesis. Our results showed that IL-20 promoted angiogenesis in vitro and in vivo [20]. These apparently contradictory findings might have been caused by different assay systems. Heuze-Vourc'h et al. used an indirect assay by treating cells with PMA and showing that IL-20 inhibited PMA-induced angiogenesis through the COX-2 regulatory pathway [66]. Other PMA-induced pathways may influence the effects of IL-20 on angiogenesis, however. It is worth exploring the different downstream signaling of IL-20 through different receptor complexes. It is possible that IL-20 regulate angiogenesis via pro- and anti- angiogenic activities in different tissues according to the microenvironment.

\section{Conclusions and perspectives}

The involvement of IL-20 in skin inflammation has been reported in several studies [32, 67, 68]. Our recent studies demonstrate IL-20 is a pleiotropic cytokine with potent inflammatory, angiogenic, and chemoattractive effects, all of which are characteristics of psoriasis, RA, and atherosclerosis. This review addresses the associations between IL-20 and these three diseases. We propose a working hypothesis of how IL-20 may be involved in the disease process summarized in the Figure 2. Epidemiological studies have demonstrated an association between the increased morbidity of atherosclerosis and RA [69, 70] and between the increased morbidity of RA and psoriasis [71-74]. Angiogenesis plays a crucial role in the pathogenesis of psoriasis and RA, and in the progression of atherosclerosis plaque. Blocking the activities of IL-20 may provide benefits in inflammationassociated diseases. Moreover, combined treatment could be used for these multi-factor diseases to alleviate their severity and slow down their progression.

In conclusion, IL-20 and its receptors are associated with many diseases. These observations give new insight into the immunobiological roles of IL-20 in different organs and suggest that IL-20 and its receptor complexes may become new therapeutic targets of drugs that block their activation in IL-20-associated diseases. These include antibodies or small molecules that neutralize IL-20, that block IL-20 cell-surface receptors, or that inhibit IL-20 intracellular signaling molecules.

\section{References}

1. Moore K.W., de Waal Malefyt R., Coffman R.L. and O'Garra A., Interleukin-10 and the interleukin-10 receptor. Annu. Rev. Immunol. 19: 683-765, 2001.

2. Moore K.W., Vieira P., Fiorentino D.F., Trounstine M.L., Khan T.A. and Mosmann T.R., Homology of cytokine synthesis inhibitory factor (IL-10) to the Epstein-Barr virus gene BCRFI. Science 248(4960): 1230-1234, 1990.

3. Thompson-Snipes L., Dhar V., Bond M.W., Mosmann T.R., Moore K.W. and Rennick D.M., Interleukin 10: a novel stimulatory factor for mast cells and their progenitors. J. Exp. Med. 173(2): 507-510, 1991.

4. Rousset F., Garcia E., Defrance T., Peronne C., Vezzio N., Hsu D.H., Kastelein R., Moore K.W. and Banchereau J., Interleukin 10 is a potent growth and differentiation factor for activated human B lymphocytes. Proc. Natl. Acad. Sci. USA. 89(5): 1890-1893, 1992.

5. Go N.F., Castle B.E., Barrett R., Kastelein R., Dang W., Mosmann T.R., Moore K.W. and Howard M., Interleukin 10 , a novel $\mathrm{B}$ cell stimulatory factor: unresponsiveness of $\mathrm{X}$ chromosome-linked immunodeficiency B cells. J. Exp. Med. 172(6): 1625-1631, 1990. 
6. Gallagher G., Dickensheets H., Eskdale J., Izotova L.S., Mirochnitchenko O.V., Peat J.D., Vazquez N., Pestka S., Donnelly R.P. and Kotenko S.V., Cloning, expression and initial characterization of interleukin-19 (IL-19), a novel homologue of human interleukin-10 (IL-10). Genes. Immun. 1(7): 442-450, 2000.

7. Blumberg H., Conklin D., Xu W.F., Grossmann A., Brender T., Carollo S., Eagan M., Foster D., Haldeman B.A., Hammond A., Haugen H., Jelinek L., Kelly J.D., Madden K., Maurer M.F., Parrish-Novak J., Prunkard D., Sexson S., Sprecher C., Waggie K., West J., Whitmore T.E., Yao L., Kuechle M.K., Dale B.A. and Chandrasekher Y.A., Interleukin 20: discovery, receptor identification, and role in epidermal function. Cell 104(1): 9-19, 2001.

8. Dumoutier L., Louahed J. and Renauld J.-C., Cloning and characterization of IL-10-related T cell-derived inducible factor (IL-TIF), a novel cytokine structurally related to IL10 and inducible by IL-9. J. Immunol. 164(4): 1814-1819, 2000.

9. Jiang H., Lin J.J., Su Z.Z., Goldstein N.I. and Fisher P.B., Subtraction hybridization identifies a novel melanoma differentiation associated gene, mda-7, modulated during human melanoma differentiation, growth and progression. Oncogene 11(12): 2477-2486, 1995.

10. Knappe A., Hor S., Wittmann S. and Fickenscher H., Induction of a novel cellular homolog of interleukin-10, AK155, by transformation of T lymphocytes with herpesvirus saimiri. J. Virol. 74(8): 3881-3887, 2000.

11. Liao Y.C., Liang W.G., Chen F.W., Hsu J.H., Yang J.J. and Chang M.S., IL-19 induces production of IL-6 and TNF-alpha and results in cell apoptosis through TNFalpha. J. Immunol. 169(8): 4288-4297, 2002.

12. Liao S.C., Cheng Y.C., Wang Y.C., Wang C.W., Yang S.M., Yu C.K., Shieh C.C., Cheng K.C., Lee M.F., Chiang S.R., Shieh J.M. and Chang M.S., IL-19 induced Th2 cytokines and was up-regulated in asthma patients. J. Immunol. 173(11): 6712-6718, 2004.

13. Dumoutier L., Van Roost E., Colau D. and Renauld J.C., Human interleukin-10-related T cell-derived inducible factor: molecular cloning and functional characterization as an hepatocyte-stimulating factor. Proc. Natl. Acad. Sci. USA. 97(18): 10144-10149, 2000.

14. Radaeva S., Sun R., Pan H.N., Hong F. and Gao B., Interleukin 22 (IL-22) plays a protective role in T cellmediated murine hepatitis: IL-22 is a survival factor for hepatocytes via STAT3 activation. Hepatology 39(5): 1332-1342, 2004.

15. Wolk K., Kunz S., Witte E., Friedrich M., Asadullah K. and Sabat R., IL-22 increases the innate immunity of tissues. Immunity 21(2): 241-254, 2004.

16. Hor S., Pirzer H., Dumoutier L., Bauer F., Wittmann S., Sticht H., Renauld J.C., de Waal Malefyt R. and Fickenscher H., The T-cell lymphokine interleukin-26 targets epithelial cells through the interleukin-20 receptor 1 and interleukin-10 receptor 2 chains. J. Biol. Chem. 279(32): 33343-33351, 2004.

17. Sheikh F., Baurin V.V., Lewis-Antes A., Shah N.K., Smirnov S.V., Anantha S., Dickensheets H., Dumoutier L., Renauld J.C., Zdanov A., Donnelly R.P. and Kotenko S.V., Cutting edge: IL-26 signals through a novel receptor complex composed of IL-20 receptor 1 and IL-10 receptor 2. J. Immunol. 172(4): 2006-2010, 2004.

18. Liu L., Ding C., Zeng W., Heuer J.G., Tetreault J.W., Noblitt T.W., Hangoc G., Cooper S., Brune K.A., Sharma G., Fox N., Rowlinson S.W., Rogers D.P., Witcher D.R.,
Lambooy P.K., Wroblewski V.J., Miller J.R. and Broxmeyer H.E., Selective enhancement of multipotential hematopoietic progenitors in vitro and in vivo by IL-20. Blood 102(9): 3206-3209, 2003.

19. Zdanov A., Schalk-Hihi C., Gustchina A., Tsang M., Weatherbee J. and Wlodawer A., Crystal structure of interleukin-reveals the functional dimer with an unexpected topological similarity to interferon gamma. Structure 3(6): 591-601, 1995.

20. Hsieh M.Y., Chen W.Y., Jiang M.J., Cheng B.C., Huang T.Y., Chang M.S., IL-20 promotes angiogenesis in a direct and indirect manner. Genes. Immun. 7(3): 234-242, 2006.

21. Dumoutier L., Leemans C., Lejeune D., Kotenko S.V. and Renauld J.C., Cutting edge: STAT activation by IL-19, IL20 and mda-7 through IL-20 receptor complexes of two types. J. Immunol. 167(7): 3545-3549, 2001.

22. Parrish-Novak J., Xu W., Brender T., Yao L., Jones C., West J., Brandt C., Jelinek L., Madden K., McKernan P.A., Foster D.C., Jaspers S. and Chandrasekher Y.A., Interleukins 19, 20, and 24 signal through two distinct receptor complexes. Differences in receptor-ligand interactions mediate unique biological functions. J. Biol. Chem. 277(49): 47517-47523, 2002.

23. Hsu Y.H., Li H.H., Hsieh M.Y., Liu M.F., Huang K.Y., Chin L.S., Chang M.S., Interleukin-20 functions as a proinflammatory molecule in rheumatoid and experimental arthritis. Arthritis. Rheum. (2006) In press.

24. Nagalakshmi M.L., Murphy E., McClanahan T. and de Waal Malefyt R., Expression patterns of IL-10 ligand and receptor gene families provide leads for biological characterization. Int. Immunopharmacol. 4(5): 577-592, 2004.

25. Wei C.C., Chen W.Y., Wang Y.C., Chen P.J., Lee J.Y., Wong T.W., Chen W.C., Wu J.C., Chen G.Y., Chang M.S. and Lin Y.C., Detection of IL-20 and its receptors on psoriatic skin. Clin. Immunol. 117(1): 65-72, 2005.

26. Wolk K., Kunz S., Asadullah K. and Sabat R., Cutting edge: immune cells as sources and targets of the IL-10 family members? J. Immunol. 168(11): 5397-5402, 2002.

27. Ding Y., Qin L., Kotenko S.V., Pestka S. and Bromberg J.S., A single amino acid determines the immunostimulatory activity of interleukin 10. J. Exp. Med. 191(2): 213224, 2000.

28. Aggarwal S., Xie M.H., Maruoka M., Foster J. and Gurney A.L., Acinar cells of the pancreas are a target of interleukin-22. J. Interferon Cytokine Res. 21(12): 10471053,2001

29. Gurney A.L. IL-22, aTh1 cytokine that targets the pancreas and select other peripheral tissues. Int. Immunopharmacol. 4(5): 669-677, 2004

30. Gottlieb S.L., Gilleaudeau P., Johnson R., Estes L., Woodworth T.G., Gottlieb A.B. and Krueger J.G., Response of psoriasis to a lymphocyte-selective toxin (DAB389IL-2) suggests a primary immune, but not keratinocyte, pathogenic basis. Nat. Med. 1(5): 442-447, 1995.

31. Asadullah K., Docke W.D., Volk H.D. and Sterry W., The pathophysiological role of cytokines in psoriasis. Drugs Today (Barc). 35(12): 913-924, 1999.

32. Romer J., Hasselager E., Norby P.L., Steiniche T., Thorn Clausen J. and Kragballe K., Epidermal overexpression of interleukin-19 and -20 mRNA in psoriatic skin disappears after short-term treatment with cyclosporine a or calcipotriol. J. Invest. Dermatol. 121(6): 1306-1311, 2003.

33. Hansen A., Cao R., Cao Y., Clausen J.T., Dissing S., Hasselager E., Myren M., Norby P.L., Olsen U.B. and 
Tritsaris K., IL-20 is an angiogenic factor in psoriasis. J. Invest. Dermatol. 124(4): A4-A4, 2005.

34. Otkjaer K., Kragballe K., Funding A.T., Clausen J.T., Noerby P.L., Steiniche T. and Iversen L., The dynamics of gene expression of interleukin-19 and interleukin-20 and their receptors in psoriasis. Br. J. Dermatol. 153(5): 911918, 2005

35. Nickoloff B.J. and Wrone-Smith T., Injection of prepsoriatic skin with $\mathrm{CD} 4+\mathrm{T}$ cells induces psoriasis. Am. J. Pathol. 155(1): 145-158, 1999.

36. Panayi G.S., Lanchbury J.S. and Kingsley G.H., The importance of the $\mathrm{T}$ cell in initiating and maintaining the chronic synovitis of rheumatoid arthritis. Arthritis. Rheum. 35(7): 729-735, 1992

37. Firestein G.S. and Zvaifler N.J., How important are T cells in chronic rheumatoid synovitis?: II. T cell-independent mechanisms from beginning to end. Arthritis. Rheum. 46(2): 298-308, 2002

38. Wipke B.T. and Allen P.M., Essential role of neutrophils in the initiation and progression of a murine model of rheumatoid arthritis. J. Immunol. 167(3): 1601-1608, 2001.

39. Walmsley M., Katsikis P.D., Abney E., Parry S., Williams R.O., Maini R.N. and Feldmann M., Interleukin-10 inhibition of the progression of established collageninduced arthritis. Arthritis. Rheum. 39(3): 495-503, 1996.

40. Finnegan A., Kaplan C.D., Cao Y., Eibel H., Glant T.T. and Zhang J., Collagen-induced arthritis is exacerbated in IL-10-deficient mice. Arthritis. Res. Ther. 5(1): R18-R24, 2003.

41. Katsikis P.D., Chu C.Q., Brennan F.M., Maini R.N. and Feldmann M., Immunoregulatory role of interleukin 10 in rheumatoid arthritis. J. Exp. Med. 179(5): 1517-1527, 1994.

42. Smeets T.J.M., Chandrasekher Y., Haringman J.J. and Tak P.P., IL-20 is expressed in inflamed synovium of patients with psoriatic arthritis and rheumatoid arthritis. Arthritis Res. Therapy 6: S9-S9, 2004.

43. Brennan F.M., Zachariae C.O., Chantry D., Larsen C.G., Turner M., Maini R.N., Matsushima K. and Feldmann M., Detection of interleukin 8 biological activity in synovial fluids from patients with rheumatoid arthritis and production of interleukin 8 mRNA by isolated synovial cells. Eur. J. Immunol. 20(9): 2141-2144, 1990.

44. Koch A.E., Kunkel S.L., Burrows J.C., Evanoff H.L., Haines G.K., Pope R.M. and Strieter R.M., Synovial tissue macrophage as a source of the chemotactic cytokine IL-8. J. Immunol. 147(7): 2187-2195, 1991.

45. Seitz M., Dewald B., Gerber N. and Baggiolini M., Enhanced production of neutrophil-activating peptide-1/ interleukin-8 in rheumatoid arthritis. J. Clin. Invest. 87(2): 463-469, 1991.

46. Villiger P.M., Terkeltaub R. and Lotz M., Production of monocyte chemoattractant protein-1 by inflamed synovial tissue and cultured synoviocytes. J. Immunol. 149(2): 722 727, 1992.

47. Koch A.E., Kunkel S.L., Harlow L.A., Johnson B., Evanoff H.L., Haines G.K., Burdick M.D., Pope R.M. and Strieter R.M., Enhanced production of monocyte chemoattractant protein-1 in rheumatoid arthritis. J. Clin. Invest. 90(3): 772-779, 1992.

48. Rathanaswami P., Hachicha M., Sadick M., Schall T.J. and McColl S.R., Expression of the cytokine RANTES in human rheumatoid synovial fibroblasts. Differential regulation of RANTES and interleukin-8 genes by inflammatory cytokines. J. Biol. Chem. 268(8): 5834-5839, 1993.
49. Koch A.E., Kunkel S.L., Harlow L.A., Mazarakis D.D., Haines G.K., Burdick M.D., Pope R.M. and Strieter R.M., Macrophage inflammatory protein-1 alpha. A novel chemotactic cytokine for macrophages in rheumatoid arthritis. J. Clin. Invest. 93(3): 921-928, 1994.

50. Feldmann M., Development of anti-TNF therapy for rheumatoid arthritis. Nat. Rev. Immunol. 2(5): 364-371, 2002.

51. Moreland L.W., Baumgartner S.W., Schiff M.H., Tindall E.A., Fleischmann R.M., Weaver A.L., Ettlinger R.E., Cohen S., Koopman W.J., Mohler K., Widmer M.B. and Blosch C.M., Treatment of rheumatoid arthritis with a recombinant human tumor necrosis factor receptor (p75)Fc fusion protein. N. Engl. J. Med. 337(3): 141-147, 1997.

52. Elliott M.J., Maini R.N., Feldmann M., Long-Fox A., Charles P., Bijl H. and Woody J.N., Repeated therapy with monoclonal antibody to tumour necrosis factor alpha (cA2) in patients with rheumatoid arthritis. Lancet 344(8930): 1125-1127, 1994.

53. Ross R., Atherosclerosis - an inflammatory disease. N. Engl. J. Med. 340(2): 115-126, 1999.

54. van der Wal A.C., Becker A.E., van der Loos C.M. and Das P.K., Site of intimal rupture or erosion of thrombosed coronary atherosclerotic plaques is characterized by an inflammatory process irrespective of the dominant plaque morphology. Circulation 89(1): 36-44, 1994.

55. Fuster V., Badimon L., Badimon J.J. and Chesebro J.H., The pathogenesis of coronary artery disease and the acute coronary syndromes (1). N. Engl. J. Med. 326(4): 242-250, 1992.

56. Lee R.T. and Libby P., The unstable atheroma. Arterioscler. Thromb. Vasc. Biol. 17(10): 1859-1867, 1997.

57. Mallat Z., Besnard S., Duriez M., Deleuze V., Emmanuel F., Bureau M.F., Soubrier F., Esposito B., Duez H., Fievet C., Staels B., Duverger N., Scherman D. and Tedgui A., Protective role of interleukin-10 in atherosclerosis. Circ. Res. 85(8): e17-e24, 1999.

58. Paterson J., Capillary rupture with intimal hemorrhage as a causative factor in coronary thrombosis. Arch. Pathol. 25: 474, 1938.

59. Tenaglia A.N., Peters K.G., Sketch M.H. Jr. and Annex B.H., Neovascularization in atherectomy specimens from patients with unstable angina: implications for pathogenesis of unstable angina. Am. Heart. J. 135(1): 10-14, 1998.

60. Chada S., Mhashilkar A.M., Ramesh R., Mumm J.B., Sutton R.B., Bocangel D., Zheng M.Z., Grimm E.A. and Ekmekcioglu S., Bystander activity of Ad-mda7: Human MDA-7 protein kills melanoma cells via an IL-20 receptordependent but STAT3-independent mechanism. Mol. Ther. 10(6): 1085-1095, 2004.

61. O’Brien E.R., Garvin M.R., Dev R., Stewart D.K., Hinohara T., Simpson J.B. and Schwartz S.M., Angiogenesis in human coronary atherosclerotic plaques. Am. J. Pathol. 145(4): 883-894, 1994.

62. Panutsopulos D., Papalambros E., Sigala F., Zafiropoulos A., Arvanitis D.L. and Spandidos D.A., Protein and mRNA expression levels of VEGF-A and TGF-betal in different types of human coronary atherosclerotic lesions. Int. J. Mol. Med. 15(4): 603-610, 2005.

63. Chen W.Y., Cheng Y.C., Lei H.Y., Chang C.P., Wang C.W. and Chang M.S., IL-24 inhibits the growth of hepatoma cells in vivo. Genes Immun. 6: 493-499, 2005.

64. Inoue M., Itoh H., Ueda M., Naruko T., Kojima A., Komatsu R., Doi K., Ogawa Y., Tamura N., Takaya K., 
Igaki T., Yamashita J., Chun T.H., Masatsugu K., Becker A.E. and Nakao K., Vascular endothelial growth factor (VEGF) expression in human coronary atherosclerotic lesions: possible pathophysiological significance of VEGF in progression of atherosclerosis. Circulation 98(20): 21082116, 1998.

65. Zeng B., Prasan A., Fung K.C., Solanki V., Bruce D., Freedman S.B. and Brieger D., Elevated circulating levels of matrix metalloproteinase- 9 and -2 in patients with symptomatic coronary artery disease. Intern. Med. J. 35(6): 331-335, 2005.

66. Heuze-Vourc'h N., Liu M., Dalwadi H., Baratelli F.E., Zhu L., Goodglick L., Pold M., Sharma S., Ramirez R.D., Shay J.W., Minna J.D., Strieter R.M. and Dubinett S.M., IL-20, an anti-angiogenic cytokine that inhibits COX-2 expression. Biochem. Biophys. Res. Commun. 333(2): 470-475, 2005.

67. Rich B.E. and Kupper T.S., Cytokines: IL-20 - a new effector in skin inflammation. Curr. Biol. 11(13): R531R534, 2001.

68. Rich B.E., IL-20: a new target for the treatment of inflammatory skin disease. Expert. Opin. Ther. Targets. 7(2): 165-174, 2003.
69. Gonzalez-Gay M.A., Gonzalez-Juanatey C. and Martin J., Rheumatoid arthritis: a disease associated with accelerated atherogenesis. Semin. Arthritis. Rheum. 35(1): 8-17, 2005.

70. Wallberg-Jonsson S., Ohman M. and Rantapaa-Dahlqvist S., Which factors are related to the presence of atherosclerosis in rheumatoid arthritis?. Scand. J. Rheumatol. 33(6): 373-379, 2004.

71. Veale D.J., Ritchlin C., FitzGerald O. (2005). Immunopathology of psoriasis and psoriatic arthritis. Ann. Rheum. Dis. 64 (Suppl 2): ii26-ii29.

72. Veale D.J. and FitzGerald O., Psoriatic arthritis - pathogenesis and epidemiology. Clin. Exp. Rheumatol. 20(6 Suppl 28): S27-33, 2002.

73. Costello P. and FitzGerald O., Disease mechanisms in psoriasis and psoriatic arthritis. Curr. Rheumatol. Rep. 3(5): 419-427, 2001

74. Kane D. and FitzGerald O., Tumor necrosis factor-alpha in psoriasis and psoriatic arthritis: a clinical, genetic, and histopathologic perspective. Curr. Rheumatol. Rep. 6(4): 292-298, 2004 